\title{
Determinants of Tax Capacity for a Territory (The Case of the Russian Federal Districts)
}

\author{
Natalia Victorova $^{1 *}$, Elena Rytova ${ }^{1}$, Lyudmila Koroleva$^{2}$, Natalia Pokrovskaia ${ }^{3}$ \\ ${ }_{1}^{1}$ Peter the Great St. Petersburg Polytechnic University, St. Petersburg, 195251, Russia \\ ${ }^{2}$ National Research Mordovia State University, Saransk, 430005, Russia \\ ${ }^{3}$ Saint Petersburg State University, St. Petersburg, 199034, Russia
}

\begin{abstract}
In this article, the tax capacity of the territories in the Russian Federation was studied. The study was conducted based on the aggregation for eight federal districts, including data on 85 subjects of the Russian Federation from 2009-2018. To determine the factors that have the strongest impact on tax capacity at the subnational level, an econometric analysis of the panel data was performed using the Stata program. In the development of the model, tax share was used as the resulting indicator. The article analyzes the impact on tax share of 16 macroeconomic indicators that reflect the human and financial potential of taxpayers in a federal district, the investment attractiveness and innovative activity of the territory, as well as global financial and economic regulators. The hypothesis that due to significant differences in the socioeconomic development of territories, the determinants of tax capacity will differ by federal districts, was confirmed. However, it was proved that such differences are not related to the specific features of socioeconomic development inherent in the constituent entities of the Russian Federation. Among the selected factors in pooled regression, fixed effects, and random effects models, the level of employment of the population and the financial results of companies were considered the most significant. The significance of the level of employment of the population could be determined by a clear deficit in gross fixed capital accumulation against the background of a high degree of depreciation of fixed assets and the share of manual labor.
\end{abstract}

Keywords: Russian federal districts; Subnational budget; Tax capacity; Tax effort; Tax share

\section{Introduction}

Sustainable development requires adequate tax policies, both at the business level (Nikolova et al., 2017; Rodionov et al., 2018; Victorova et al., 2019) and the state level (Chernogorsky and Shvetsov, 2018; Konnikov et al., 2018; Kharlamov and Kharlamova, 2019). Tax capacity is one of the three key state capacities (Besley and Persson, 2009; Besley and Persson, 2013) that can stimulate economic growth (Gaspar et al., 2016; Chernogorskiy et al., 2017) and sustainable development (Berawi, 2016; Berawi, 2018; Moeis et al., 2020). Tax revenues are a necessary source of sustainable development, which enhances the capability of the state to generate its tax revenues. This issue is of particular importance from a territorial standpoint, especially for federal states such as Russia (Gutman et al., 2018; Romashkina et al., 2018; Zaborovskaya et al., 2019). 
The tax capacity characterizes the ability of the region to generate tax revenues. The assessment of this indicator identifies the potential for increasing tax capacities, although this increase is not always guaranteed. In other words, taxation in the region is not necessarily aimed at achieving a maximum tax capacity. However, the proper assessment of the tax capacity is extremely important for building a tax system that is relevant to the tasks of the state. In the study of a country's tax capacity, a wide range of actions can be undertaken to increase the actual indicators by changing the tax system, taking into account all economic and social implications. However, at the level of subnational budgets, the task becomes more unambiguous (i.e., to identify possible areas for increasing tax revenues with the given parameters of taxation, within the framework of a single tax field). The solution to this problem allows the debugging of the mechanisms of the financial equalization of budgets. Thus, subnational tax capacity is closely related to budget capacity (Pechenskaya, 2018).

Although tax capacity is assessed to forecast the potential tax revenues of budgets, actual data on tax revenues is used to calculate its determinants. After finding the relationship between tax revenues and their determinants, it is possible to search for influential factors to increase the tax effort.

\section{Literature View}

There are different approaches to assessing the ability of a particular region to generate tax revenues. These differences are determined by calculating the tax capacity and its determinants.

The correlation-regression approach is most widely used. The development of models that explain the tax opportunities of countries from the second half of the twentieth century, was discussed in a study by Gurnak (2013). The review shows that empirical research was evolving by taking into account more factors that affect tax opportunities of the state. Thus, Gupta (2007) conducted a study that included data from 105 developing countries over 25 years and revealed the relationship between tax revenues and GDP per capita, the share of agricultural products in the GDP, openness of trade, the volume of foreign aid, the level of corruption, political stability, and in addition, the relationship between direct and indirect taxes. The value of tax revenues in relation to GDP was used as a target indicator of assessment in a study by Le et al. (2008), which analyzed changes in tax capacity in 104 countries. The characteristics of economies, as well as demographic and institutional parameters, were chosen to explain the trends. The importance of taking into account the relationship between the development of institutions and the amount of tax revenues was also confirmed by Bird et al. (2008). A recent study by Dalamagas et al. (2019) justified the predominant influence on tax revenues of two economic factors: GDP as a characteristic of production potential and consumer preferences. Despite the numerous tax capacity models available, the architecture of tax systems in many developing countries is characterized by paradoxes (Gordon and Li, 2009). This is in sharp contrast with the developed systems and theoretically justified optimal models.

An alternative tax effort research methodology is stochastic frontier analysis. In the first stage of this analysis, the maximum value of tax revenues is estimated by taking into account the determinants used. In the second stage, factors that determine the discrepancy between the actual tax revenues and the maximum value are analyzed. This approach is applied in research (Alfirman, 2003; Pedraja et al., 2020). These methods have been criticized by Cyan et al. (2014) for their lack of connection with national conditions, in particular with the amount of government spending. The comparison of tax revenues and government spending is even more important when analyzing the tax capacity of 
subnational budgets. At the subnational level, the tax system is externally determined, and the possibility of increasing tax revenues is analyzed within specified tax bases. A separate area of the study of a regions' tax opportunities (Maxwell, 1972; Berry and Fording, 1997) is the influence of decentralization and changes in tax powers within the country (Besfamille and Sanguinetti, 2004; Schneider, 2006; Huang et al., 2012). For example, the cases of India (Naganathan and Sivagnanam, 2000; Purohit, 2006) and China (Liu and Zhao, 2011; Han and Kai-SingKung, 2015; Jia et al., 2020) demonstrate that financial transfers reduce local tax efforts.

Garg et al. (2017) found that in the states of India, there was a positive relationship between tax revenues and the GRP per capita and the share of the economically active population and their literacy rate, while the relationship between tax revenues and the share of the agricultural sector was negative. The study of tax capacity in the regions of Spain (Zarate-Marco and Valles-Gimenez, 2019) showed a relationship between tax revenue and the population, as well as its income. However, the most interesting finding, in our opinion, was the division of regions into groups depending on the level of use of the tax potential, as well as the differentiation of tax capacity determinants for different regions. Similar results were obtained previously at the municipal level (Valles-Gimenez and ZarateMarco, 2017). Studies of the regional tax opportunities in Russia are often conducted in terms of the tax capacities at a subnational level (Martinez-Vazquez and Boex, 1997; Alexeev et al., 2019).

The aim of this study was to determine the factors that have major influences on the tax capacity at the subnational level in the Russian Federation.

Based on the literature review, the first hypothesis of the study was developed: tax capacity depends on the main macroeconomic indicators that determine the size of the tax base for the budget-forming taxes of the Russian Federation.

Another feature of the Russian fiscal system is the excessively high variation in economic and social indicators among the different regions. Obviously, the regions of Russia have their own features that affect tax capacity. In order to determine the key determinants of tax capacity, the analysis of the data from eight federal districts, involving seven to eighteen constituent entities of the Russian Federation was conducted. The results that are obtained from a more integrated examination of the regions can outline the areas for further in-depth study on individual subjects of the federation. There are also differences among federal districts, but they are significantly smaller than those among individual regions. This made it possible to consider a federal district as a territory that geographically unites several constituent entities of the Russian Federation to assess the average value of tax capacity.

Taking into account the conclusions for the regions of Spain (Valles-Gimenez and Zarate-Marco, 2017; Zarate-Marco and Valles-Gimenez, 2019), as well as the differences among the territories in Russia, the second hypothesis of the study was as follows: due to significant differences in the socioeconomic development of territories, the determinants of tax capacity will differ by federal district.

Our work dealt with the territorial aspect of tax revenues at all levels of the budget system of Russia. To achieve the goal of the study, correlation and regression modeling of the indicators of tax and non-tax revenues at the subnational level (including regional and local budgets) and gross regional product was used.

\section{Methods}

The subject of this study is the relationship between the tax share and macroeconomic indicators of the economy in the federal districts of the Russian Federation. 
The research methodology was based on the concepts that consider taxation to be an effective instrument of state regulation of the economy. The study was carried out using general scientific methods as well as econometric methods.

To confirm the hypotheses of the study, the analysis of a data panel containing statistical information on various factors describing the same set of objects (federal districts) over a number of consecutive time periods was used.

At the first stage of regression analysis, factors that can influence the dependent variable were selected. In this study, the hypothesis assumed that there are significant causal relationships between the tax capacity of the territory and its macroeconomic indicators that reflect various aspects of the development of the federal district: labor and employment, living standards, investment and innovation, industrial production, and finance. The macroeconomic indicators that were used as predictors were selected with due account for previous research on factor analysis of tax revenues in the consolidated budget of Russia and the regions, as well as for the hypotheses formulated in this study. The set of variables was formed on the available statistical base for the federal districts of the Russian Federation. The research was based on official data from the Federal State Statistics Service, as well as statistical reports from Russian tax authorities.

The tax share variable was selected as the dependent variable. The tax share indicator was calculated as the ratio of tax and non-tax revenues collected in the analyzed territory to budgets of all levels, not including the amounts of taxes and social insurance premiums received by extra-budgetary funds, to the gross regional product. To calculate the tax share of the federal districts, aggregated indicators for the constituent entities of the Russian Federation were taken.

Regression analysis of data was performed using the Stata package. For the 16 selected indicators, a correlation analysis was performed in the first stage to assess the presence and direction of relations. Then, various versions of the models were constructed, each of which was tested for compliance with the provisions of the Gauss-Markov theorem. Finally, the model with the best characteristics from the entire set of tests performed was selected.

\section{Results and Discussion}

The tax share indicator (Figure 1) showed smaller differences among 7 out of 8 federal districts due to the assessment of tax and non-tax revenues by GRP.

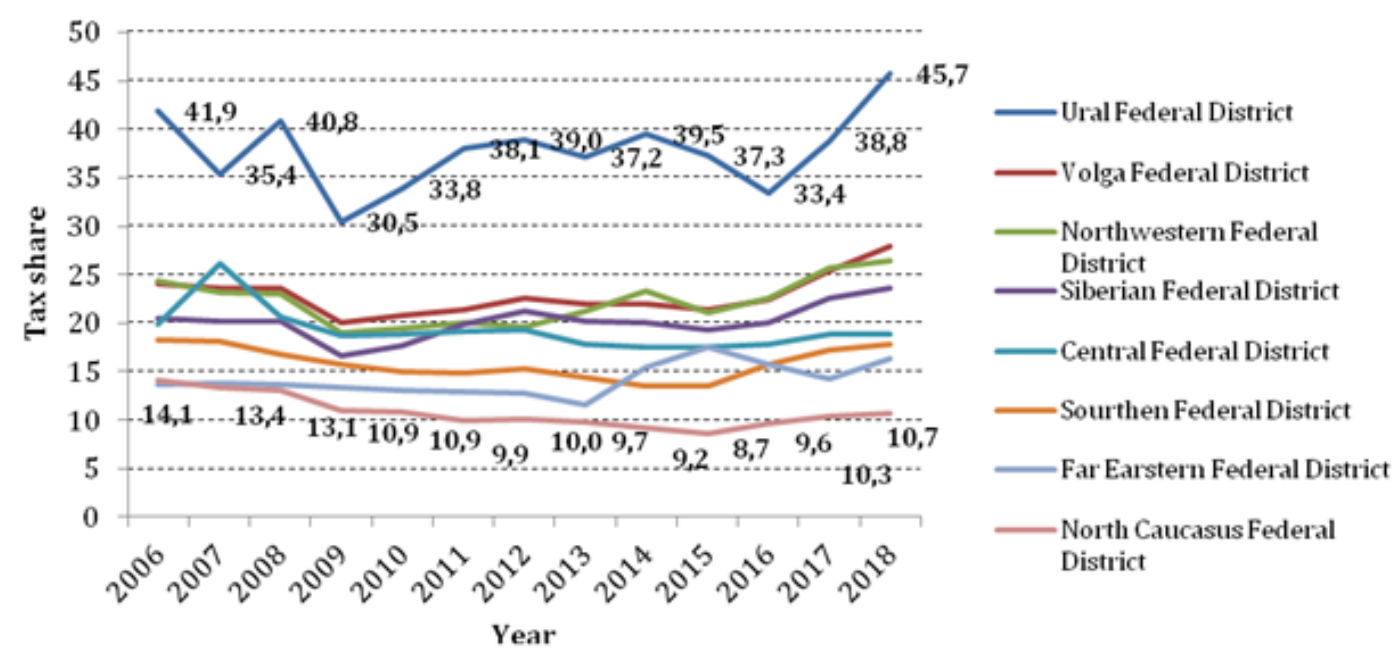

Figure 1 Tax share in the federal districts of the Russian Federation (\%) 
At the same time, the differences in the dynamics of the indicator in the federal districts provided arguments in support of the second hypothesis about the differences in the determinants of tax capacity by region.

The tax share curves clearly show a significant reduction in the indicator for 2009 for all federal districts of the Russian Federation in response to the crisis of 2008-2009. Therefore, the econometric analysis was carried out on the data from the post-crisis period, 2009-2018.

The preliminary analysis in this research involved the study of the correlation matrix. From the correlation matrix, it can be concluded that tax share had a weak correlation with most of the selected indicators at the federal district level.

A regression analysis on pooled data was performed. The results of the regression analysis are shown in Table 1.

In general, the model produced was significant. Although the coefficient of determination was quite high, most of the coefficients for variables were insignificant. At the first stage of testing, the model was analyzed for outliers or influential observations. Various tests for outliers were carried out. The studentized residuals and leverage were evaluated to identify observations that were not typical for the sample. No errors were found in the data. However, testing allowed the establishment of two observations with a high value of residuals and leverage. These were observations for the Central Federal District in 2016 and 2018. Based on the analysis, the significant influence of these two observations on the model coefficients was determined, and a decision was made to remove them from the analysis, which significantly improved the quality of the model. Table 1 shows the adjusted model, however, most of the model coefficients are still insignificant.

Table 1 Regression analysis on pooled data and adjusted model comparison

\begin{tabular}{|c|c|c|c|c|}
\hline $\mathrm{N}$. & Name of the factor & Model variables & $\begin{array}{l}\text { Pooled } \\
\text { regression }\end{array}$ & $\begin{array}{c}\text { Pooled regression } \\
\text { without outliers }\end{array}$ \\
\hline $\mathrm{X} 1$ & the number of workers aged 15 to 72 & Workforce & $\begin{array}{c}0.004 \\
(0.009)\end{array}$ & $\begin{array}{c}0.003 \\
(0.008)\end{array}$ \\
\hline $\mathrm{X} 2$ & $\begin{array}{l}\text { average annual number of employed } \\
\text { residents }\end{array}$ & Employment & $\begin{array}{l}-0.003 \\
(0.009)\end{array}$ & $\begin{array}{l}-0.002 \\
(0.008)\end{array}$ \\
\hline X3 & $\begin{array}{l}\text { level of employment among the population } \\
\text { aged } 15 \text { to } 72\end{array}$ & Employmentrate & $\begin{array}{l}0.922^{*} \\
(0.429)\end{array}$ & $\begin{array}{l}1.134^{* *} \\
(0.366)\end{array}$ \\
\hline $\mathrm{X} 4$ & per capita income & Incomepercapita & $\begin{array}{c}0.0003^{*} \\
(0.0001)\end{array}$ & $\begin{array}{c}0.0001 \\
(0.0001)\end{array}$ \\
\hline X5 & consumer spending per capita, on average & $\begin{array}{l}\text { Consumerspendings } \\
\text { percapita }\end{array}$ & $\begin{array}{l}-0.0002 \\
(0.0003)\end{array}$ & $\begin{array}{l}-0.00005 \\
(0.0002)\end{array}$ \\
\hline X6 & $\begin{array}{l}\text { the index of physical volume of } \\
\text { investments in fixed assets (in comparable } \\
\text { prices) against the previous year }\end{array}$ & Physicalvolumeind & $\begin{array}{c}0.097 \\
(0.078)\end{array}$ & $\begin{array}{c}0.011 \\
(0.068)\end{array}$ \\
\hline X7 & $\begin{array}{l}\text { number of enterprises and organizations at } \\
\text { the end of the year }\end{array}$ & Enterprises & $\begin{array}{l}-0.016 * \\
(0.007)\end{array}$ & $\begin{array}{c}-0.030 * * * \\
(0.007)\end{array}$ \\
\hline $\mathrm{X} 8$ & $\begin{array}{l}\text { industrial production index against the } \\
\text { previous year }\end{array}$ & $\begin{array}{l}\text { Industrialproduction } \\
\text { ind }\end{array}$ & $\begin{array}{l}-0.541^{* *} \\
(0.148)\end{array}$ & $\begin{array}{l}-0.366^{* *} \\
(0.130)\end{array}$ \\
\hline X9 & $\begin{array}{l}\text { balanced financial result (profit minus } \\
\text { loss) from organizations' performance }\end{array}$ & Financialresult & $\begin{array}{c}0.004^{* * *} \\
(0.001)\end{array}$ & $\begin{array}{c}0.009 * * * \\
(0.001)\end{array}$ \\
\hline $\mathrm{X} 10$ & $\begin{array}{l}\text { the specific weight of unprofitable } \\
\text { organizations }\end{array}$ & Unprofitableorg & $\begin{array}{l}-0.638 \\
(0.342)\end{array}$ & $\begin{array}{l}-0.208 \\
(0.322)\end{array}$ \\
\hline X11 & consumer price index & Consumerpriceindex & $\begin{array}{c}0.248 \\
(0.209)\end{array}$ & $\begin{array}{c}0.340 \\
(0.179)\end{array}$ \\
\hline $\mathrm{X} 12$ & $\begin{array}{l}\text { the volume of innovative products in the } \\
\text { total volume of goods, works, and services } \\
\text { supplied }\end{array}$ & Innovativegoods & $\begin{array}{l}-0.426^{* *} \\
(0.139)\end{array}$ & $\begin{array}{l}-0.350^{*} \\
(0.122)\end{array}$ \\
\hline $\mathrm{X} 13$ & $\begin{array}{l}\text { the share of fixed capital investment in } \\
\text { GRP }\end{array}$ & InvestmentsinFA & $\begin{array}{l}0.446^{*} \\
(0.208)\end{array}$ & $\begin{array}{c}0.264 \\
(0.180)\end{array}$ \\
\hline
\end{tabular}




\begin{tabular}{|c|c|c|c|c|}
\hline $\mathrm{X} 14$ & $\begin{array}{l}\text { exchange rate of the US dollar to the } \\
\text { Russian ruble (average annual rate) }\end{array}$ & USexrate & $\begin{array}{l}-0.173^{*} \\
(0.072)\end{array}$ & $\begin{array}{l}-0.185^{*} \\
(0.061)\end{array}$ \\
\hline $\mathrm{X} 15$ & $\begin{array}{l}\text { the share of wholesale trade turnover in } \\
\text { GRP }\end{array}$ & Wholesaletrade & $\begin{array}{l}-0.112^{*} \\
(0.044)\end{array}$ & $\begin{array}{l}-0.048 \\
(0.040)\end{array}$ \\
\hline $\mathrm{X} 16$ & $\begin{array}{l}\text { Ural's average crude oil price for the year, } \\
\text { (calculated at the average annual exchange } \\
\text { rate of the US dollar to the Russian ruble) }\end{array}$ & Uralsoilprice & $\begin{array}{c}1.707 \\
(1.047)\end{array}$ & $\begin{array}{c}0.821 \\
(0.905)\end{array}$ \\
\hline & Constanta & & $\begin{array}{c}20.897 \\
(46.218)\end{array}$ & $\begin{array}{l}-30.721 \\
(40.676)\end{array}$ \\
\hline \multicolumn{5}{|c|}{ Model parameters } \\
\hline & $N$ & & 80 & 78 \\
\hline & $R^{2}$ & & 0.758 & 0.809 \\
\hline & $R^{2} a d j$ & & 0.656 & 0.756 \\
\hline & $R M S E$ & & 4.681 & 3.971 \\
\hline
\end{tabular}

Standard errors in parentheses.

${ }^{*} p<0.05,{ }^{* *} p<0.01,{ }^{* * *} p<0.001$

This is because, at the specification stage, macroeconomic indicators with high degrees of interdependence were included in the model in order to select the factors that had the greatest impact on the result. Therefore, multicollinear factors were undoubtedly present in the model. The model was analyzed for the multicollinearity of factors, and unnecessary factors were excluded. As a result, 12 out of 16 factors remained in the model. Indicators for labor resources were excluded, except the share of the employed population, as well as consumer spending per capita, which is closely related to per capita income.

After that, the analysis for linearity was performed. A number of factors in the model did not have a linear relationship with the result. To resolve the problem, factor conversion can be performed. The logarithm was found for the per capita indicator, which contributed to the achievement of greater linearity. Thus, factors with pronounced non-linearity were excluded from the model. Then, the factors for which the coefficient remained insignificant were excluded, one after another. As a result, only four factors remained in the model: the level of employment among the population aged 15 to 72; the share of wholesale trade turnover in GRP; the balanced financial result (profit minus loss) from organizations' performances; and the percentage of innovative goods in the total volume of goods, works, and services supplied. Of the indicators examined, the level of employment and the percentage of innovative products had the greatest importance for tax share. The coefficient of determination was $63 \%$, meaning that the variance of the selected factors can explain up to $63 \%$ of the variance of the resulting indicator (Table 2).

However, the adjusted coefficient of determination was lower in the pooled regression, which might indicate that there were problems with the model specification. Hence, tests for the model specification were conducted. To evaluate the specification, the Ramsey omitted variable test (OV test) and link test were performed. Both of them indicated problems with the specification (OV test: $F(3,70)=5.8$; Prob $>F=0.0013$ ). This could have been deduced without testing, since not all potential influencing factors were taken into account in the development of the model. This is primarily due to the shortcomings of the statistical base for federal districts, which was used in the study.

Although there are problems with the specification, the model residuals were evaluated for normality and heteroscedasticity. To test normality, a graphical test and a Shapiro-Wilk test $(\mathrm{z}=0.998$; Prob $>\mathrm{z}=0.159$ ) were performed. According to the tests, the distribution of residuals was close to normal. To test for heteroscedasticity, the graphical test and the Breusch-Pagan $\left(\mathrm{chi}^{2}=9.86\right.$; Prob $\left.>\mathrm{chi}^{2}=0.0017\right)$ and White $\left(\mathrm{chi}^{2}=3.13\right.$; Prob $>\mathrm{chi}^{2}=0.0014$ ) tests were used. According to the tests, the residuals of the model are heteroscedastic. In itself, some heteroscedasticity is characteristic of real economic data, 
but when combined with specification problems, this leads to incorrect estimates for the model, which will not only be biased, but also be ineffective.

Table 2 The results of regression analysis: pooled regression, fixed effects regression, and random effects regression

\begin{tabular}{cccc}
\hline Model variables & Pooled regression (final) & Fixed effects model & Random effects model \\
\hline Employmentrate & $1.419^{* * *}$ & 0.125 & 0.198 \\
& $(0.220)$ & $(0.175)$ & $(0.182)$ \\
Financialresult & $0.005^{* * *}$ & $0.003^{* * *}$ & $0.003^{* * *}$ \\
& $(0.001)$ & $0.001)$ & $(0.001)$ \\
Innovativegoods & $-0.474^{* * *}$ & -0.004 & -0.022 \\
& $(0.119)$ & $(0.058)$ & $(0.061)$ \\
Wholesaletrade & $-0.197^{*}$ & $0.949^{*}$ & 0.060 \\
& $(0.029)$ & $(0.032)$ & $0.032)$ \\
Constanta & $-57.990^{* * *}$ & 3.421 & 0.922 \\
$-e$ & $(13.176)$ & $(10.674)$ & $(11.254)$ \\
$-u$ & & & 5.237 \\
Model parameters & & & 1.790 \\
$N$ & 78 & 78 & 78 \\
$N_{g}$ & & 8 & 8 \\
$R^{2}$ & 0.634 & 0.096 & 0.147 \\
\hline
\end{tabular}

Standard errors in parentheses.

${ }^{*} p<0.05,{ }^{* *} p<0.01,{ }^{* * *} p<0.001$

In general, a significant model was obtained. However, the quality of the model was low, and hence, it cannot be used for forecasting and real-life estimates. However, it confirms the dependence of the tax share indicator on a number of macroeconomic indicators. Thus, the first hypothesis of the study was confirmed.

To test the second hypothesis, fixed effects and random effects models were also built (Table 2). In both models, the coefficients for factor variables were insignificant, except for the variable for the balanced financial result (profit minus loss) from organizations' performance. To choose between a fixed effects or random effects model, it is possible to use the Hausman test, in which the null hypothesis would indicate that the preferred model should be a random effects model. The test checks whether unique errors (ui) correlate with regressors. The null hypothesis states that there is no correlation between unique errors and regressors. In this case, the Hausman test confirmed the null hypothesis, (i.e., of

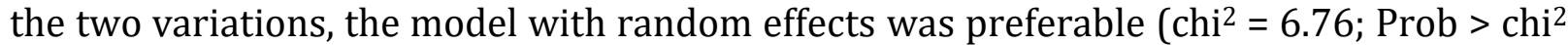
$=0.1489$ ).

The Lagrange multiplier test (LM test) proposed by Breusch and Pagan allows the choice between a random effects regression and a pooled regression. The null hypothesis of the LM test indicates that the span between the objects is zero. This means that there is no significant difference between the units (i.e., there is no panel effect). Here, the null hypothesis was rejected, and it was concluded that a random effects regression was appropriate. This indicated significant differences between districts, so a pooled regression could not be used, since a panel effect was present.

Based on the results of the analysis of the fixed and random effects models, as well as pooled regression, it can be concluded that the second hypothesis is not unreasonable. Indeed, the differences between federal districts were significant. At the same time, these differences are not of a systemic nature and do not appear to be as a result of some individual characteristics inherent in each federal district, as is usually the case in the analysis of regions. This is probably due to the way the data was aggregated for the district level. 
However, the analysis failed to identify a sufficiently high-quality model for forecasting and management. Among the selected factors at this stage of the study, the level of employment of the population and the financial results of companies were the most significant. The significance of the level of employment of the population was determined by a clear deficit in gross fixed capital accumulation (21\% of GDP according to 2019 data) against the background of a high degree of depreciation of fixed assets $151.4 \%$ in manufacturing and 55.9\% in mining) and the share of manual labor.

In the future, the set of indicators under examination will be expanded, and an analysis at the regional level will be conducted to create models more suitable for forecasting and management purposes.

\section{Conclusions}

The results of the study confirmed both hypotheses: (1) the tax capacity of federal districts is determined by the main macroeconomic indicators that affect the size of the tax base of budget-generating taxes; (2) the determinants of tax capacity differ significantly across federal districts. Thus, these results are consistent with those from previous studies.

In future research, the indicators for federal districts that reflect the digital transformation both in terms of tax administration and the performance of taxpayers' obligations to the state will be included in the modelling process. However, from a practical standpoint, it is promising to uncover the tax capacity determinants for individual constituent entities of the Russian Federation. As our work has shown, it may be appropriate to analyze the constituent entities of the federation by clusters united by similar socioeconomic characteristics. This will make it possible to build inter-budgetary relations in the most effective way, solve problems of regional subsidies, and contribute to the sustainable development of territories.

\section{Acknowledgements}

This research work was supported by the Academic Excellence Project 5-100 proposed by Peter the Great St. Petersburg Polytechnic University.

\section{References}

Alexeev, M., Avxentyev, N., Mamedov, A., Sinelnikov-Murylev, S., 2019. Fiscal Decentralization, Budget Discipline, and Local Finance Reform in Russia's Regions. Public Finance Review, Volume 47(4), pp. 679-717

Alfirman, L., 2003. Estimating Stochastic Frontier Tax Potential: Can Indonesian Local Governments Increase Tax Revenues under Decentralization? University of Colorado at Boulder. Working Paper, pp. 03-19

Berawi, M.A., 2016. Accelerating Sustainable Infrastructure Development: Assuring WellBeing and Ensuring Environmental Sustainability. International Journal of Technology, Volume 7(4), pp. 527-529

Berawi, M.A., 2018. Managing Sustainable Infrastructure and Urban Development: Shaping a Better Future for ASEAN. International Journal of Technology, Volume 9(7), pp. 12951298

Berry, W., Fording, R., 1997. Measuring State Tax Capacity and Effort. Social Science Quarterly, Volume 78(1), pp. 158-166

Besfamille, M., Sanguinetti, P., 2004. Exerting Local Tax Effort or Lobbying for Central Transfers. Econometric Society Latin American Meetings, p. 249 
Besley, T., Persson, T., 2009. The Origins of State Capacity: Property Rights, Taxation, and Politics. American Economic Review, Volume 99(4), pp. 1218-1244

Besley, T., Persson, T., 2013. Taxation and Development. Handbook of Public Economics, Volume 5, pp. 1-81

Cyan, M., Bird, M., Vulovic, V., 2014. New Approaches to Measure Tax Effort. In: Taxation and Development: The Weakest Link? Edward Elgar, pp. 27-68

Bird, R., Martinez-Vazquez, J., Torgler B., 2008. Tax Effort in Developing Countries and HighIncome Countries: The Impact of Corruption, Voice and Accountability. Economic Analysis and Policy, Volume 38(1), pp. 55-71

Chernogorskiy, S., Kuporov, Ju., Shvetsov, K., 2017. Evaluating Marginal Excess Burden of Taxation in Russia and the USA. In: Proceedings of the 30 IBIMA Conference, pp. 27522757

Chernogorsky, S., Shvetsov, K., 2018. A Model of Economic Growth, including Taxation and Public Sector. In: Proceedings of the 31st IBIMA Conference, pp. 988-995

Dalamagas, B., Palaios, P., Tantos, S., 2019. A New Approach to Measuring Tax Effort. Economies, Volume 7(3), pp. 1-25

Garg, S., Goya, A., Pa, R., 2017. Why Tax Effort Falls Short of Tax Capacity in Indian States: A Stochastic Frontier Approach. Public Finance Review, Volume 45(2), pp. 232-259

Gaspar, V., Jaramillo, L., Wingender, P., 2016. Tax Capacity and Growth: Is there a Tipping Point? International Monetary Fund Working Papers, p. 16

Gordon, R., Li, W., 2009. Tax Structures in Developing Countries: Many Puzzles and a Possible Explanation. Journal of Public Economics, Volume 93(7), pp. 855-866

Gupta, A., 2007. Determinants of Tax Revenue Efforts in Developing Countries. International Monetary Fund. Available Online at https://www.imf.org/external/pubs/ft/wp/2007/wp07184.pdf, Accessed on November 20, 2020

Gurnak, A., 2013. Empirical Studies of Tax Opportunities in Different Countries. Industrial Economics, Volume 1-2(62), pp. 231-251

Gutman, S., Rytova, E., Kravchenko, V., 2018. System of Regional Indicators for Sustainable Development of the Far North Regions. In: Proceedings of the 31 IBIMA Conference, pp. 1843-1852

Han, L., Kai-SingKung, J., 2015. Fiscal Incentives and Policy Choices of Local Governments: Evidence from China. Journal of Development Economics, Volume 116, pp. 89-104

Huang, Jr., Lo K., She P., 2012. The Impact of Fiscal Decentralization on Tax Effort of China's Local Government after Tax Sharing System. Singapore Economic Review, Volume 57(1), pp. 1-22

Jia, J., Ding, S., Liu Y., 2020. Decentralization, Incentives and Local Tax Enforcement. Journal of Urban Economics, Volume 115, https://doi.org/10.1016/j.jue.2019.103225

Kharlamov, A., Kharlamova, T., 2019 Sustainable Development of the Russian Economy in the Context of Global Instability. In: Proceedings of the 33 IBIMA Conference, pp. 822830

Konnikov, E., Konnikova, O., Ivanov, S., Novikova, O., 2018. Instrumentation of Ensuring the Sustainability of the Tax System. In: Proceedings of the 30 IBIMA Conference, pp. 52185225

Le, T., Moreno-Dodson, B., Rojchaichaninthorn, J., 2008. Expanding Taxable Capacity and Reaching Revenue Potential: Cross-Country Analysis. The World Bank

Liu, Y., Zhao, J., 2011. Intergovernmental Fiscal Transfers and Local Tax Efforts: Evidence from Provinces in China.Journal of Economic Policy Reform, Volume 14(4), pp. 295-300 
Martinez-Vazquez J., Boex, J., 1997. Fiscal Capacity: An Overview of Concepts and Measurement Issues and their Applicability in the Russian Federation. Georgia State University

Maxwell, J., 1972. The Adequacy of State and Local Tax-Effort. Publius, Volume 1(2), pp. 6976

Moeis, A.O., Desriani, F., Destyanto, A.R., Zagloel, T.Y., Hidayatno, A., Sutrisno, A., 2020. Sustainability Assessment of the Tanjung Priok Port Cluster. International Journal of Technology, Volume 11(2), pp. 353-363

Naganathan, M., Sivagnanam, K., 2000. Federal Transfers and Tax Efforts of States in India. The Indian Economic Journal, Volume 47(4), pp. 101-110

Nikolova, L., Rodionov, D., Litvinenko, A., 2017. Sustainability of the Business in the Conditions of Globalization. In: Proceedings of the 30 IBIMA Conference, pp. 417-421

Pechenskaya, M., 2018. Budget Capacity in the System of Capacities of the Territory: Theoretical Issues. Economic and Social Changes: Facts, Trends, Forecast, Volume 11(5), pp. 61-73

Pedraja, F., Polo, C., Suarez-Pandiello, J., 2020. Evaluating Fiscal Effort in Heterogeneous Contexts using a Conditional Nonparametric Frontier Approach. Applied Economics, Volume 52(7), pp. 710-725

Purohit, M., 2006. Tax Efforts and Taxable Capacity of Central and State Government. Economic and Political Weekly, Volume 25, pp. 747-55

Rodionov, D., Konnikov, E., Konnikova, O., 2018. Approaches to Ensuring the Sustainability of Industrial Enterprises of Different Technological Levels. Journal of Social Sciences Research, Volume 3, pp. 277-282

Romashkina, G., Didenko, N., Skripnuk, D., 2018. Socioeconomic Modernization of Russia and its Arctic Regions. Studies on Russian Economic Development, Volume 28(1), pp. 2230

Schneider, A., 2006. Who Gets What from Whom? The Impact of Decentralisation on Tax Capacity and Social Spending. Commonwealth \& Comparative Politics, Volume 44(3), pp. 344-369

Valles-Gimenez, J., Zarate-Marco, A., 2017. The Tax Effort of Local Governments and its Determinants: The Spanish Case. Annals of Economics and Finance, Volume 18(2), pp. 323-348

Victorova, N., Vylkova, E., Pokrovskaia, N., Shukhov, F., 2019. Information Technology and Innovation in Taxpayer Registration and Numbering: National and International Experience. In: Proceedings of the 2019 International SPBPU Scientific Conference on Innovations in Digital Economy

Zaborovskaya, O., Kudryavtseva, T., Zhogova, E., 2019. Examination of Mechanisms of Regional Sustainable Development Strategy as Exemplified by the Leningrad Region. International Journal of Engineering and Advanced Technology, Volume 9(1), pp. 50655076

Zarate-Marco, A., Valles-Gimenez, J., 2019. Regional Tax Effort in Spain. Economics, Volume 13, pp. 1-32 